Justyna Deręgowska, Ph.D.

College of Humanities and Journalism

\title{
SOCIAL SUPPORT AND THE PROSPECTS OF SOCIOPSYCHOLOGICAL DEVELOPMENT OF CHILDREN WITH ONCOLOGICAL DISEASE
}

\section{Children and their Oncological Disease - an Outline}

Although recent years have brought vast advancements in children's oncology and hematology, oncological diseases continue to be the second most important cause of death of children and youths both in Poland as well as abroad.

Every year 1500 children are diagnosed with cancer which kills 300 of them. Each year 2200 children undergo chemotherapy and 6000 require close followup. There are far more children suffering from the disease than the ones that are actually diagnosed with it (Tojza, 2003). The most frequent types of cancer that children are diagnosed with are leukemia (35\%), tumors located within the central nervous system (22\%) and lymphangiomas (10\%) (Binnebesel, 2003).

Unfortunately, over $8 \%$ of patients with apparently cured disease, suffer from recurrence within 20 years. (Kowalczyk, Samardakiewicz, 1998).

According to the definition suggested by the Commission of Chronic Diseases, a disease is qualified as a chronic one when it involves "any dysfunctions and deviations from the normal which are permanent, cause disability, is caused by irreversible pathological changes, requires special rehabilitation or the patients suffering from it might require a long-term follow-up, observation and care". (Adamczak, 1998, p.11). Thus an oncological disease might be classified as a chronic one as it has its characteristic course and carries a risk of immediate or long-term complications.

Nowadays, children's oncological diseases are considered in numerous aspects. In the biological one, the disease causes anatomical changes of particular organs and distorts their physiological functions. From the medical point of view, this constitutes "a distortion of the functions of the organism and its regulatory mechanisms" (Gomułka, Rawerski, 1995). Psychological concepts treat the disease as "an event in the process of development", the source of frustration which 
makes it impossible to satisfy the most basic needs, releasing negative emotional reactions, weakening cognitive activity, delaying the processes of socialization and threatening psychological, physical, social and intellectual development (Skorny, 1986, Obuchowska, Krawczyński, 1991). Cancer may also have a psychological aspect as it carries terrible suffering, changes the way the child perceives and evaluates many everyday issues, causes bodily pain and alters the way the sick child reacts to all these difficulties (Kulmatycki, 2008).

\section{Developmental Disorders and Disability as Consequences of Oncological Disease and Its Treatment}

Developmental psychology defines development as "a long term process of structured and progressive changes leading from lower, simple and less organized forms and states, to the higher, more complex and better organized ones which aims at balancing the individual's relationships with its environment" (Pilecka, 2011, p. 25).

In view of the above, the developing organism of a child should aim at reflecting the surrounding world, its individuality as well as the relations between the two. At the same time, the development should aim at objectivization of cognition and autonomization of activities which, in time, should be more and more internally controlled (Pilecka, 2011). However, when taking into account the close bonds between health, disease and development, it becomes clear that the specifics of the oncological disease, its course and treatment reach far beyond the limits of a child's emotional immunity. In most children, the disease destroys their fundamental ability to adapt to unfavorable circumstances which is so important for a child's correct development. Cancer distorts all the spheres of life - the biological, the psychological as well as the social and spiritual ones.

As Eiser's, Hille's and Vance's research show (2000: Pilecka, 2011), 30\% of children with cancer clearly do not cope with the requirements and limitations which result from the disease. As a consequence, the children experience major difficulties with their social and emotional life. Their academic results are usually worse than their healthy peers'. They are unable to enter into close and permanent peer relationships.

The developmental costs borne by children with cancer are not only caused by the disease itself; also the troublesome and unpleasant treatment negatively influences their development. This may lead to developmental disorders and even to disability, i.e. the functions of their organisms deteriorate which limits or at least makes it difficult to fulfill the child's social roles. The limitations may affect the child's physical functions as well as the psychological ones. The disability may be temporary or permanent. It can have a primary character, which results from the 
disease itself and which negatively affects the child's physical and psychological stamina; the disability affects either the central or the peripheral nervous system. The disability may also be of a secondary character when it results from the pathological changes within the child's organism. i.e. from general dysfunctions of the body which are caused by the progressing disease.

Unfortunately, all the cancer treatment procedures burden the patient's organism. Cytostatics used in chemotherapy have numerous neurotoxic side effects; they destroy central and peripheral nervous systems which may impair intellectual development. Chemotherapy may cause vegetative symptoms, hearing impairment and slow down psychological and motor reactions. Radiation which is used in oncological radiotherapy causes unpleasant side effects such as nausea, vomiting, skin lesions and hair loss. Radiation of the brain causes deterioration of intelligence levels by one standard deviation which distorts intellectual development. Hormonotherapy does not only cause endocrinological problems but also very adverse neurological complications as well as numerous complications of circulatory system, breathing, digestive system, bone and muscle system as well as it may be destructive to many organs of the body. Moreover, surgical procedures which are sometimes necessary to remove the cancerous tissue together with a safe margin of the healthy tissue and elements of lymphatic system, may call for removing a part or the whole organ. There may also be problems with healing of post-operative wounds (Nyka, Dziewulska - Bokiniec, 1997).

Most frequently cancer treatment is a combined treatment which involves all the possible methods. This calls for interdisciplinary and invasive approaches which in any case cause the child a lot of suffering (Kowalczyk, 2006). The combined treatment increases the risk of developmental disorders which may appear as acute effects, like some somatic side effects, as well as the sub-acute symptoms and the delayed effects. The latter include decreased level of intellectual development as well as neurological deficiencies manifested by deterioration of shortterm memory, difficulties with concentration, dysfunction of motor and perception functions, inadequate math skills and learning difficulties. The delayed effects may reveal themselves several years after the treatment is completed (Pilecka, 2011). All these cause difficulties in social life and lead to numerous failures in the future (Buczyński, 1999, Pietrzyk, 2001).

Although cancer and its treatment expose the child to permanent changes which are caused by radical surgical procedures, a time-consuming treatment, possible relapses and acute attacks of the disease, it must be stressed that the permanent pathologic changes do not only occur in the child's body but in its psychological sphere as well. They affect some structures of personality and its social adjustment abilities.

The mere invasiveness of the treatment exposes the child to long lasting psychical pain but also the spiritual, psychological and social suffering. The timeconsuming treatment involves hospital regimens and isolation from the child's 
natural pedagogical environment, its family and its peers which the child finds extremely difficult to accept. Moreover, cancer treatment exposes the child to many difficult situations resulting from medical procedures, completely new living conditions and activity. The young patient suffers because there may be different situations related the the progress of treatment or the lack of it (Maciarz, 1998, Tojza, 2003). In consequence, the disease permeates and distorts all the spheres of the child's life and development; it becomes a threat to the process of shaping its personality. It evokes the feeling of being in a state of menace, stress and physical or emotional strain.

Another problem related to oncological treatment is lengthy hospitalization which deprives the child of many needs and causes the so called hospitalism syndrome. This is manifested by slower physical and psychological development as well as emotional apathy. Clinical image of this syndrome involves aggression, avoidance and isolation as well as long-term effects in the emotional and motivational spheres: hypersensitivity, emotional lability, reacting with fear to new situations, resentment, decreased self-control, depressive behavior All these when combined, constitute a serious risk factor which may manifest itself in the child's social functioning.

To sum up, oncological disease creates a very unfavorable context for the young patient's development; it is a risk factor in all of its areas. It is responsible for the quality and quantity of changes. The results of the disease and treatment are seen as unique deficiencies that affect many spheres of life. Some of them may be minimized by specialist pharmacotherapy or physiotherapy, most result in permanent dysfunctions is psychosomatic sphere and social life of the child. The effects influence their academic results and future life. Even if the treatment proves to be effective, the child freed from the disease, forever remains a person who suffers from physical, psychological or psychophysical disability.

\section{Minimizing the Negative Effects of the Oncological Disease on the Child's Development - a Postulative Status}

As biological determinism is currently becoming less popular, the disease is perceived as a biological and social phenomenon. In addition, the unfavorable effects of cancer and its treatment on the child's development are stressed. Therefore, attention is drawn to the necessity to introduce auxiliary treatment and minimizing the negative effects of therapy by offering systematic and planned psychological and social support to the young oncological patient. The child's problems must be considered not only in the categories of family and hospital environment as these two contexts constitute intertwined layers of the child's life and they definitely influence its life in the future. The importance of proper care, 
pedagogical and therapeutic activities cannot be underestimated in preventing the negative effects of the disease on the child's development. What is needed is the patient's active participation in the process of treatment. All their psychological needs must be satisfied; they must be treated with dignity and approached on an individual basis. Any support offered to them needs to be composed of preventive and reparatory measures (Samardakiewicz, 2011).

The above aspects are included in the standards prepared by SIOP(International Committee on Psychosocial Issues in Pediatric Oncology) of 1991 defining how to treat the patients (Kowalczyk, Samardakiewicz, 1998).

The recommendations concern the following areas:

- psychosocial care and support given to the patient;

- educational issues and teaching children with cancer;

- communicating the diagnosis;

- cooperation between parents and healthcare personnel;

- accompanying the child in the terminal period of the disease;

- the issues related to the child's healthy siblings;

- counteracting the professional burnout syndrome;

- extending care over the survivors.

In 2000, in Poland a national research program was started which aims at introducing the methods of psychosocial support offered to children with cancer. The methodology was prepared by SIOP. A wide scope of psychosocial support was suggested; it offered psychological aid to every sick child, suggested doing psychological research and documenting the assistance as well as offering psychological interventions. Moreover, in the centers of pediatric oncology and hematology, a uniform model of communicating the diagnosis to the child and its parents was assumed. The Polish Group of Pediatric Psycho-oncologists founded in September 2006 on the decision of the Polish Association of Pediatric Oncologists and Hematologists started to monitor the program of supporting the development of children with oncological diseases (Samardakiewicz, 2011).

\section{Supporting a Child with Cancer in Light of Current Research Studies}

Despite the fact that in Poland there are currently 17 specialized pediatric hematology and oncology centers, not all the elements of psychosocial support have yet been started. And even if they have, they are not always adequate to the patients' needs. The above is based on the research carried out on pediatric hematology, oncology and transplantology wards in a major clinical center.

The research focused mainly on crisis situations within the family and manners of coping with the crisis, showed that there is also a need to support each family member, and especially the young oncological patient. Based on the research, 
areas of social practice were shown where intensified actions need to be taken in support of the patient on all stages of the disease. These include the time when the diagnosis is made and communicated to the patient, when the patient is hospitalized and at home where the treatment is continued.

In order to enhance the importance of the task, the author quotes below some excerpts from conversations with young oncological patients and their parents.

\section{Social Support Offered to a Child at the Time of Diagnosing its Oncological Disease}

Considering the results of the examinations, one may conclude that although not all of the suspicions of oncological diagnosis are later confirmed, all of the children who find themselves in this situation experience this period as utterly difficult and stressful. All the events preceding the final diagnosis are very important and the emotions accompanying children awaiting the diagnosis combined with unfavorable hospital environment have a destructive effect on the patient's well being.

In that difficult period children trigger their defensive mechanisms so to lessen the emotional burden but at the same time all of them find it extremely difficult to deal with the situation. The only source of support which reaches them in that period is their family support. Unfortunately, it is inadequate. What would be necessary is some professional support satisfying their emotional needs. This kind of assistance is not usually offered at the time the diagnosis is made.

Neither the children nor their parents are informed by the medical personnel about the ongoing diagnostic process which makes the time of waiting for the results especially stressful. Moreover, in that difficult period the young patients are not supported by a professional psychologist. This is important as the diagnostics is usually carried out while the children are hospitalized and thus confronted with the suffering of other patients. This extremely stressful situation is reflected in the following interview with one of the mothers: "The mere entering the oncology ward and my first moments there were horrible. What you sometimes see on TV is nothing, does not compare to the reality there. On TV everything looks... well, not bad. But my husband, my daughter and me saw that quite differently... The children were locked up in small rooms, their heads completely hairless... there were pipes and tubes everywhere, IV drops connected and, oh God, how they vomited. It was so very, very sad and horrible; we were so depressed. I am generally a positive and optimistic person but that view, that atmosphere, and my daughter there... I was so devastated that I did not even know how I felt. I guess I was terrified; the fear froze all my body as if all my internal organs stopped working. As if I froze". 


\section{Social Support Offered to the Child and their Parents at the Time of Communicating the Diagnosis}

Another period is the time when the diagnosis is communicated to the child and its parents who are affected by extremely strong stress. They experience negative emotional reactions; they cannot motivate themselves to find out the needed information, they are unable to control their emotions or behavior. The situation breaks them down, they are "frozen", alienated, helpless, they panic which is a classical reaction to any loss or any trauma. This state should immediately inspire psychological intervention but it is not granted to any of the parents. And it should be as the parents' behavior has a very strong effect on the child's emotional state and perception of its own situation.

The following excerpt from an interview with one of the mothers illustrates the moment when oncological diagnosis was communicated to her: "In the room when they told me about this, there was no sofa, not even a chair. I just slid down the door... I remember that there was a nurse who gave me some pills. I felt as if somebody just tripped me. You cannot describe the feeling, it was as if the world collapsed".

The time of communicating the diagnosis involves not only the reactions to the disease and hospitalization but also the difficulties to adjust to these, with ambivalent attitudes of the adults towards communicating the truth to the child: "A young lady doctor told me, the one that everybody kind of liked, that I should not hide anything from my child... what he is sick with and what operations await him. This surprised me... 'cause before I had noticed that other doctors and nurses did not use to call the disease by its name, that they were very secretive about it. They said that kids were not supposed to know what was wrong with them".

Communicating the diagnosis to the child or not communicating it is primarily the responsibility of doctors and parents. However, healthcare personnel do not take any concrete stand and even if they think that the child should be told about cancer and its consequences, they do not offer parents any assistance in this respect. The differences of outlooks on that issue are huge and the discrepancies have a negative effect on the young patient. One of the mothers remembers the moment of communicating the diagnosis as follows: "So when I found out the diagnosis, he saw me crying... so I had to tell him something, right? The doctor promised to come and talk to us but she did not, and he kept asking me why I was crying all the time and he cried too. He was weeping and weeping. I just could not take it. He wiggled and cried to go home, he kicked and bit me. I was helpless, I was crying all the time, I was embarrassed by that but could not help it, could not cope with it, I did not know what to do with him..."

The diagnosis is frequently hidden from the child. From its parents' viewpoint, this protects the child from anxiety, however, it frequently increases the 
fear. Parents want to support the child by avoiding the conversations on the disease, by not answering their questions, pretending to treat the disease very lightly and giving the child only the positive information. However, they do not always realize that all that may not help their child who can see the discrepancy between the verbal messages he receives and the non-verbal message of despair and sadness which they get from their parents.

It is also necessary to pay attention to teenagers as their emotions are not only triggered by the fact that they must stay in hospital, but also by the fact that they realize what the disease involves and what its consequences might be. A teenage patient is aware of the threats posed by the disease. When the diagnosis is communicated to them, they are filled with shock, disbelief and high levels of anxiety.

Frequently even the moment when the diagnosis was communicated to them stays in their memory for ever. They remember it as a traumatic experience not only due to the content of such information but also due to the form it was conveyed by the medical personnel. It can be seen in words of one of teenagers: "I remember that the nurse told me to go to the doctors' room. When I went in, there was only the doctor and a nurse. And then... they hit it right at me... They said I had leukemia and that this was the first stage... so there was no need to get depressed. They kept saying something about the disease... but... I did not hear that. I was scared and shocked. They gave me a book to read (everybody gets it)... I never read that book, because when I started, I knew I was unable to grasp all that... I was unable to cope with what the book said..."

Communicating the diagnosis to children, as Borysławska says (2002, p. 90), should be done in the same circumstances as it is done with adult patients. Moreover, it should be preceded with a discussion which could allow to evaluate the psychoemotional state, the patient's level of knowledge and expectations. The author believes that the first message about the diagnosis should come from competent personnel, i.e. from the doctors who made the diagnosis. The information should be complete, true and, first of all, well adjusted to the intellectual level of the sick child.

In the initial period of the disease, the child stays in hospital which regardless of the patient's age is a stressful and challenging experience. At that stage, the attitude towards the disease is formed as a result of certain emotional and cognitive processes. The hospital, as a characteristic microenvironment, becomes a place perceived by the young patient as hostile and unpleasant. It causes frustration, evokes the feeling of deprivation, and harms the child's emotional structure. The child is absolutely helpless in view of the disease and completely dependent on other people. It must take on another role in life, the role of a sick person, which affects all areas of its activity. The child does not form defense mechanism immediately. Moreover, it lives in the environment of tension which its parents feel. The lack of information and the subjective reactions which are frequently inadequate to the circumstances make the patient feel that there is no need to stay in 
hospital, that there is a definite discrepancy between what the child feels and what its parents decide. One of the children suggestively presents its own feelings in the very first moments on the oncology ward: "When they brought us here, then it was immediately the oncology ward... Frankly speaking, this was a terrible shock to us... hard to describe it... The hairless children, pale as paper, so quiet... They put me to bed... I felt I was shivering but I did not know if that was because I was so scared or so cold, or what... The feeling was so strange that I cannot describe it. What I had seen on TV before... the kids with leukemia... or hospitals, well that was just nothing compared to that.. I found myself among such children ... One huge fear..."

As the research shows, at the time of communicating the diagnosis, there is no professional psychological support, let alone psychological intervention whose importance is stressed so strongly by numerous psychologists.

The only support is the emotional bond between the children and their parents. It alleviates the traumatizing effect of the disease, as family constitutes an important link of emotional support. This kind of support, however, is not always adequate as the extreme situation calls for professional psychological intervention.

\section{Supporting the Child During Hospitalization}

Oncological procedures are used to treat children involve numerous stays in hospital. The patients' life oscillates around long periods of hospitalization and short periods of staying at home. The hospital becomes part of their life, another home and the periods of hospitalization are so important for them. The research shows that, at the time of hospitalization, there are many situations adding more trauma and offering only negative experiences to the suffering children.

First of all, the hospital circumstances make the patient completely subdued to the medical personnel. Therefore, in addition to the stress related to the disease itself, the child is also experiencing the so called hospital stress. The child's psyche is excessively burdened and although it is not prepared to this, the child undertakes its individual struggle with the disease and the new requirements it is faced with. The following opinions of the respondents point to the fact that the hospital conditions are perceived very negatively both by the children as well as their parents:

"I hate this hospital, these flaking paint on the walls, the windows, the bed, I hate being locked up there, I hate it...".

"What is so scary here is the fact that you are locked in one small room... you are not allowed to leave... just the bed and two meters to the bathroom, and that is it. You cannot even sit at the table because it is too small. If two kids wanted to sit at it, to eat lunch, the plates would not fit there. At the table, there are just 
two chairs, sometimes three so you have to eat your dinner in bed, you do your schoolwork in bed too. I cannot really understand... that the kids are so locked up in their rooms. When they really have to, well that is different but none of them can leave their rooms, none at all...".

Sick children frequently are unable to cope with stress which affects their organisms and weakens their defensive forces. Then withdrawal begins to dominate and causes bad effects of the child's development, lowers its self-esteem and gets it rid of any plans for the future. This is frequently interpreted as adaptation to the new conditions and professional assistance is not granted to such child. The patient experiences the feeling of disorganization, helplessness, fear and loneliness. It is impossible for them to externalize the negative emotions. The hospital environment blocks any expression of anger and so the negative feelings cumulate. This destructively affects the patient's personality.

The hospital rigor forbids the child to get in touch with its siblings which increases the feeling of loneliness. As a result, the patient misses the siblings and the feeling is mutual. This situation builds up anxiety with the children who remain at home. Several excerpts from interviews with sick children illustrate their negative experiences of hospitalization:

"None of the doctors or nurses even bothered to talk to me seriously... I don't know what they thought but they must have thought I wasn't even there... just the bottles with chemo which they kept changing... I felt so bad there, so impersonal... so empty... The only people that ever talked to me, consoled me and explained anything were the other kids and their parents... I didn't know anything then how everything worked on the ward... It was just... a total shock..."

"He just crawled into his shell, became depressed. He refused to talk with anybody... did not speak to anyone... neither to the doctor nor to the nurses, not even to me. He was either lying with his back turned to me or he kept his eyes closed as if he was sleeping. He didn't say a single word to me. That was just horrible 'cause I didn't know what to do. I kept begging him... I cried... I wanted him to get back, I even yelled at him. But he did not react. Just kept turning his back on me. Nobody came there then. A psychologist? Forget it... I was begging for some help for him... Everybody, even doctors, could see what was going on with him but nobody... no one even tried to help him somehow..."

"So I spent 13 months in hospital, I had those thoughts, that it was so sad... that I felt so lonely... Even then I just didn't feel like talking to anyone ... I just wanted to be in bed... I pretended I was sleeping. And they treated me like that. They just kept changing the IV drops, they examined me but nobody talked to me, neither the doctor nor the nurses. Not that they were angry with me... they just didn't talk. I didn't feel like talking either, what could I say?... I don't know if there even was a psychologist to see me. But is don't think so. Sometimes just the other kids... I felt terrible, but I somehow returned to myself... I guess I regretted that I was back to this horrible world. And ever since I have been really fed 
up... I keep lying in my bed and I don't speak, even if I do, it is very rarely I say something..."

With time, every child develops their own manner of coping with the situation; they develop some mechanisms which most frequently involve aggressive behavior, emotional lability; they begin to mistrust adults which may be observed in the opinion below.

"Oh, he was impatient; he would cry and moan... sometimes he screamed at me, he would hit me, out of the blue. He just could not stand all that. He had never been sick before... My boy... he knew that I was crying all the time, that I was sad. He cried to, sometimes he was unbearable; when he finally let me leave I always had to buy something for him. He could be bad to other adults too. Once he even spat on one lady. He would scratch me and hit me... He just could not take the hospital any longer."

The medical personnel usually do not inform the child as to what diagnostic procedures and treatment they are planning to apply. This causes iatrogenic stress. Research carried out amongst the young patients and their parents points to the fact that they are all convinced that the less the child knows about the negative aspects of the disease, the better it is for the child. The subject of cancer is not discussed and very few members of the medial personnel are able to offer psychological support which could prepare the children for the lengthy medical procedures and treatment. This is but one of the examples how lightly the issue of satisfying the patients' cognitive needs is treated by the personnel (Maciarz, 2006, p. 34). As Tobiasz-Adamczyk (2002) points out, a child is able to understand the issues related to its health better than it is generally believed. Direct communication between the child and its doctor may positively influence the results of treatment. It could constitute a form of social support which could motivate the child to fight the disease and be the source of positive thinking. Patients are often treated as objects which may be seen in the following interview.

"And then I asked the doctor whether to tell me boy about the operation but he said absolutely not. On the next day, from the early dawn doctors would go to and fro. They were to operate on my son. Even then I asked them if I should tell him and then another lady doctor told me that definitely yes, that I had to tell my child about the operation... What was I supposed to to? My son kept asking, he was very nervous. No wonder, after all those tests... He did not want to stay in hospital, he was fed up with everything I think he could sense it..... I was at a complete loss whether to tell him or not. Nobody helped me decide. Some of them said yes, the others said no. But the decision was mine. In the end, I did not tell the child about the operation. I told him that he would be taken for some more tests... He was just looking at me.. that strange look... He could sense that. He had trusted me. He asked several times and I lied to him...I did not know what was best. I just did not know... They took him to the theater just like that, completely not prepared." 
The information the child gets about the disease, its effects and options of treatment is very scarce hence the inadequate and incorrect image of their own disease that the child has to live with. All the time the patient witnesses numerous personnel behaviors which may be qualified as iatrogenic and offers nothing but more stress which the child is unable to cope with. The only thing left to them is to automatically react defensively and - frequently - irrationally.

The lack of psychological preparation to the procedures and diagnostics is extremely painful to children. Another unbearable fact is the limitation of their physical activity which results from hospital rigors that cannot always be justified by hygienic requirements. Additionally there is idleness, boredom, monotony and the personnel's emotional indifference, their disregard for the child's cognitive needs and their autocratism. As one of the mothers says, the children are not at all informed about the scheduled treatments.

"Well, usually a nurse comes in and tells the child that he will be taken for a lumbar puncture. This stress is just unimaginable for a child. For the doctors it is a routine procedure but for the child it is not so routine. The ones that have had it already take it calmly but some kids are scared, they cry and find it unbearable. Just like my son at the beginning. Nobody told him anything, they just took him there and that was it..."

Medical personnel does not take any trouble to inform the child about the methods of treatment, they are not interested in psychological problems the child may have, they are not patient, they do not want or have time to listen to the child. There is no therapeutic context to alleviate the fear of procedures and operations. This depresses the child even more, evokes the feelings of restlessness, anxiety and generally deteriorates the well-being of the young patient. This in turn may lead to the appearance of new neurosis-related symptoms which delay healing and may leave permanent traces in the child's psyche.

Undoubtedly, the changes in the child's social activity caused by their hospitalization influence the course of the disease. The changes depend on interpersonal relationships occurring in the hospital and beyond it. Very negative stances frequently develop amongst those who surrounded the patient who feels rejected by their peers and other people who used to be close to them. The child feels insecure, lonely and lost. The bonds with the former environment are broken and the child's teachers rarely organize any support for the little patients.

The issue of schoolwork cannot be underestimated since the child must learn most school subjects even though the learning process is much slower and it is carried out in very basic educational environment. Despite the inconvenience, the fact that the child carries on learning, getting school marks and sustaining its educational readiness may satisfy the child's cognitive as well as social needs. The prospects of returning to school one day offers support to the child's emotions; it offers security and self-esteem (Chęcińska, 2005). Schoolwork introduces the elements of ordinary life into the hospital reality and allows the child to focus on 
something else than the disease (Binnebesel, 2002). It introduces some variety in the life of the child suffering from persistent boredom.

Some teachers offer support to their students not only by concrete educational activities but also by showing them some understanding, having interesting conversations with their patient-students thus achieving the goals of therapeutic pedagogy. Unfortunately, the role of hospital teachers is frequently limited to teaching and realizing the compulsory academic curriculum. The teachers working in hospitals are only supported by one pedagogue who is usually unable to fulfill the needs of all the patients.

Needless to say, the situation of hospitalized teenagers who have almost reached their physical maturity is even more difficult. Before the disease, they usually have very good relations with their peers, they have created fairly realistic image of themselves, defined some purposes and plans for the future. They are very much aware of the dangers their disease may carry and they find it hard to accept that their life has changed so drastically. Such patients suffer from very particular types of problems. They confront their situation with the need to be independent. Their appearance is very important to them just as is the opportunity to fulfill their hopes and ambitions. They suffer because of the loss of control of their own lives which they perceive as a threat in their attempt to be independent as well as their ability to decide for themselves.

The lack of psychological support is very painful; without it, teenagers are unable to carry burden of the disease. Their maturity is not respected and thus they are seldom included in the therapeutic process which could at least give them a sense of control of the decisions which, after all, affect them (Kowalczyk, Samardakiewicz, 1998).

One may easily notice that all sick children, regardless of their age, are forced to cope with two types of crisis - a developmental one as well as the situational one. The problems multiply and the patients are deprived of the opportunity to carry on with their positive development.

There is no doubt that the disease calls for much more that just medical intervention; psychological and social support is essential as well (Maciarz, 2001). The research shows that theoretical knowledge is not supported by practical activities. In hospital practice there seems to be an abyss between understanding the young patient's emotional state and the real actions taken by the personnel to support the child. Understanding the necessity of psychological support is never accompanied with concrete actions. The child needs professional support but does not get it in spite of the fact that there is a psychologist working full time on the ward. The only support the patient may count on is offered by their family, especially their mother as well as by their own defense mechanisms which are so limited by the disease and hospitalization. The child is not offered any systematic therapeutic support which is so important in the struggle against the disease. Almost all of the respondents stressed that fact. 
"It is not humanly possible to understand that in the situation when assistance is needed immediately everybody treats you as if you were not there. Before the psychologist decided to devote some of her precious time to her, and she knew everything about my daughter, several days went by... I was appalled as I think that in such situation, although the psychologists works until $3 \mathrm{pm}$, she should come in the evening. This is a child we are talking about!"

"None of us had a chance to talk to the psychologist, we did not even get in touch with her, none of us... (...) Here in the ward, I think, the assistance is terrible, some people should not even be working here... I do not think that the psychologist even works here, even though they physically are on the ward. I sometimes lose it, just like the other ones but there is no help in sight... Zero. Nobody ever offered me any help with that."

\section{Support Offered to Children in the Period of Maintenance Therapy}

Most children continue their treatment at home. All of them call for very regular follow-up and rehabilitation in the somatic and psychological aspect.

The joy of coming back home is usually blurred by strong stress which influences the child's adaptive abilities and emotions, their will and their aims. The child still has to cope not only with physical disabilities and limitations but also with social difficulties. They all add up to create one huge set of complications and limitations which make it so difficult for the child to re-adapt to family life. The problems result from the disease itself as well as from the stressful hospital treatment as the emotional state of the child is strongly affected by both of them.

The child is simply unable to be just like before the illness. Adaptive efforts are usually accompanied by memories and experiences related to the disease and treatment (the threat of complications, death, anxiety, the changed appearance and frustration resulting from not being able to participate in ordinary life). The child is unable to accept the new routines as they deprive them of the feeling of control of their own life, security. In return the new lifestyle offers nothing but limitations.

The child needs to be more mature that its healthy peers, more disciplined which is needed in any therapy. Its everyday life is marked by fear of recurrence resulting with another hospitalization. The young patient is still confronted with the haunting thoughts of death, especially when they find out that their friend from oncology ward has lost their battle. The living space is limited by struggle with pain, anxiety and loneliness.

The stamina and energy levels drop and the child is very reluctant to deal with new tasks. It becomes suspicious and distrustful; its self-esteem deteriorates and isolations tendencies increase. With time, resignation comes, the child becomes very compliant and submissive as they see themselves as helpless and dependent on the others. The problem is illustrated in the following interviews: 
"She has such moments when she creeps in her shell, as if she was not there. She is sad, impatient, irritable... sometimes even she is so angry as if she wanted to hit me..."

"But the worst thing is that I don't even like my house any more. There is not a single place I miss. I feel so bad and insecure everywhere. This has been going on for too long and I think I am going mad..."

Parents sacrifice a lot of time and effort to the sick child. They become more tolerant and accept much disobedience which they would find unacceptable in the past. They tolerate aggression with which they did not use to put up before the disease. The sick child's problems begin to dominate in the family, that breeds more conflicts and stress. As a result - the whole family suffers.

The children come back home and they return to school. At the beginning, the child is taught by teachers who come to their house. At that time, it is very important that besides teaching particular subjects, the teachers should reintroduce the child to their old school, friends and environment. According to Maciarz (1996) this issue is frequently neglected by teachers. Individual learning has many drawbacks. First of all, teachers focus on several school subjects and ignore the psychological needs the child may have. They rarely initiate contacts between the child and its old classmates. That could be of major importance for the socializing processes not only for the sick child but also for its friends. The patient's educational needs are ignored. As the following opinion suggests, education plays a vital therapeutic role in the life of a sick child: "As far as learning is concerned, the worst are my daughter's teachers. When she is at home, and she has to stay home very often, they need to come and teach her. But here they don't. None of the teachers wants to come in the afternoon, it is either too late or too dark... anyway, they cannot get to us. As I said, they have already checked her out. My daughter does not exist for them any more. Once I went to see the principal but without any result. Now I am totally powerless. I am just so sorry that she lags behind with the material, she used to be such a good student..."

The necessity to make use of the available re-educational programs is frequently disregarded. The rules outlined in the official document prepared by the Psychosocial Committee at the International Organization of Pediatric Oncology are not followed.

Having returned to school, the child finds it difficult to fulfill the roles of a students and a member of its peer group. It poorly adapts to teachers' requirements and the norms of their peer groups. It cannot fulfil its social roles. Very few teachers take up any activity in order to offer the child some emotional support. Neither the classmates nor the school personnel are prepared to accept the child and there are numerous misunderstandings related to the disease. Some peer reactions are unacceptable; they make comments on the child's appearance, ask unpleasant questions, etc. As the following excerpt from an interview with one of mothers shows, the return of the chronically sick child to their peers can be 
extremely difficult: "She refuses going to school completely, she does not even want to meet their friends. No wonder... She is fed up with all the unpleasant remarks, laughing, staring, the comments on the fact that she has no hair, all that... She does not want to come back to this school and I have to organize teachers coming home to teach her. She said that she might want to go to a new school but she does not want to see her old classmates. I cannot force her, but she does not want to meet anyone, she would rather stay home all the time..."

Another negative fact is the reluctance of healthy children to get into interaction with the sick ones. This seems to be caused by certain negligence on the part of educators who do not encourage healthy children to accept their sick friends. On the other hand, nobody seems to make an effort to increase their self-esteem and teach them how to interact with their healthy classmates (see Maciarz, 1998). A sick child who has to cope with their peers' negative attitudes, perceives the fact that being "different" means being "worse". Such a youngster finds it difficult to accept themselves; their assertiveness disappears. They are certain that they cannot deal successfully with particular roles so they do not assume the role. In consequence, the sick child becomes socially isolated. They are prone to frustration caused by the reactions of their peers; they lose their need for motion, emotions, intellectual activity as well as social interaction. There is a suggestive description of a sick child's mothers which illustrates the above:

"My son was at home then... that was shortly before the third recurrence. He was still able to walk then. It was Children's Day and our local authorities organized a bonfire for the kids. My son wanted to play with kids so he and his sister went there. Unfortunately, there were no sausages left for them to roast. The village kids started calling him names. They mocked him because he was swollen, bald and fat. My son was limping then but he managed to run back home in tears... My daughter was crying so hard that I was unable to calm her down. She was trying to protect him there but she couldn't. Oh, how we all cried! Even I did. Later I went to see the principal but he did not do much".

In view of the above, one may anticipate that some of the problems will emerge and the ones that already exist will increase. The child may express emotional indifferentism, aggression, it suffers from isolation and avoids social interactions; there comes a lack of self-esteem and helplessness; they may be prone to neurotic behavior, suffer from intellectual, emotional and social development retardation; they may be unable to satisfy their needs of acceptance and considerably slow down the process of socializing.

There is np doubt that all sick children staying at home need professional psychological support. Their parents are generally aware of that need, yet they cannot access such assistance or they find it difficult to get some support for their children. They frequently do not know who to turn to. Emotional support offered to children by their parents is inadequate and professional help is rarely granted. Professionals are mostly hired by their parents despite limited financial abilities; some simply 
cannot afford to pay for such specialists. Let us not forget that according to psychooncologists, "only a well designed and carried out physical, psychological and social rehabilitation may lead to true healing" (Kowalczyk, Samardakiewicz 1998, p. 42).

\section{Conclusions}

Despite the disease which poses a real threat to the child's psychological and physical development, the young patient still needs to develop. For that reason the treatment, care and education must be assisted by specialists - an interdisciplinary team of doctors, physiotherapists, psychologists and educators. The team's cooperation with the child and its family could alleviate or at least limit the negative consequences of the disease. Unfortunately, as has been shown by the research, this postulate is not implemented. Although the study was carried out on concrete, individual cases, it may be generally concluded that the support offered to such children is not of universal character and that there are too few specialists who are motivated and competent enough to provide the children with professional psychological assistance.

Despite the fact that the contemporary culture highly values life and health, the problems of children coping with cancer seem to be neglected. In light of the interviews, psychological support is as much inadequate as it is necessary. As a consequence, the therapeutic aims are not reached, the efficacy of treatment is much below expectations. Moreover, the child's psychological and social development is in danger.

The adequate support still remains in the sphere of plans, although "social support given to the patient with cancer should definitely bring about positive health effects" (Wrześniewski, Włodarczyk, 2000, p. 172). The support is designed based on health related objecitves which are specific to the patient's situation. It must take psychophysical unity and objective situational requirements into consideration. The support needs to aim at minimizing the negative psychosocial consequences of the disease. Therefore, social support should be designed in view of the complex situation that the sick child finds itself in, the place where the child is treated, the phase of treatment, its psychophysical condition, its age and personality traits, as well as general and economic circumstances in the family.

\section{References}

Adamczak M. (1998). Wybrane procesy poznawcze i emocjonalne u kobiet po mastektomii, p. 11. Poznań: Wyd.Naukowe UAM.

Binnebesel J. (2003). Opieka nad dziećmi i młodzieża z choroba nowotworowa $w$ doświadczeniu pacjentów. Toruń: Wyd. Uniwersytetu Mikołaja Kopernika. 
Borysławska A. (2002). Psychoterapia z chorobami nowotworowymi krwi [In:] Sońta - Jakińczyk D.

[Ed.]. Choroby krwi i układu krwiotwórczego u dzieci. Katowice: Śląska Akademia Medyczna.

Buczyński F. L. (1999). Rodzina z dzieckiem chorym na białaczk., Lublin: Katolicki Uniwersytet Lubelski.

Chęcińska M. (2005). Realizacja obowiązku szkolnego przez dziecko przewlekle chore [In:] Kott T.

[Ed]: Uczeń z przewlekłą chorobą i zaburzeniami psychicznymi w szkole ogólnodostępnej.

Warszawa: Ministerstwo Edukacji Narodowej i Sportu.

Gomułka W., Rawerski W. (1995). Encyklopedia zdrowia. Warszawa: PWN.

Kowalczyk J. (1998). Onkologia dziecięca w Polsce - osiagnięcia i wyzwania [In:]

http://www.brpd.gov.pl/szczyt/prof.j.kowalczyk.htm [20.10.2012]

Kowalczyk J. R., Samardakiewicz M. Dziecko z choroba nowotworowa. Warszawa: Wydawnictwo Lekarskie PZWL.

Kulmatycki L. (2008). Zdrowie i dobrostan psychiczny [In:] Woynarowska B. [Ed.]: Edukacja

zdrowotna. Podręcznik akademicki. Warszawa: PWN.

Maciarz A. (1996). Dziecko dtugotrwale chore. Zielona Góra: Wyd. Verbum.

Maciarz A. (2006). Dziecko przewlekle chore. Opieka $i$ wsparcie, p. 34. Warszawa: Wyd. Akademickie Żak.

Maciarz A. (2001). Pedagogika lecznicza i jej przemiany. Warszawa: Wyd. Akademickie Żak.

Maciarz A. (1998). Psychoemocjonalne $i$ wychowawcze problemy dzieci przewlekle chorych. Kraków: Oficyna Wydawnicza Impuls.

Nyka W., Dziewulska-Bokiniec A.(1997). Niepełnosprawność fizyczna jako skutek leczenia onkologicznego. Psychoonkologia, 1.

Obuchowska I., Krawczyński M. (1991). Chore dziecko. Warszawa: Wyd. Nasza Księgarnia.

Pietrzyk A. (2001). Diagnoza: nowotwór złośliwy - jak z tym żyć? Czy tak postawione pytanie może stać się pytaniem naukowym? [In:] Popiołek K. [Ed.]. Człowiek w sytuacji zagrożenia. Poznań: Stowarzyszenie Psychologia i Architektura.

Pilecka W. (2011). Psychologia zdrowia dzieci i młodzieży jako dyscyplina stosowana [In:] Pilecka W. [Ed.]. Psychologia zdrowia dzieci i młodzieży. Perspektywa kliniczna. Kraków: Wyd. Uniwersytetu Jagiellońskiego.

Samardakiewicz M. (2011). Wspomaganie rozwoju dzieci z choroba nowotworowa [In:] Antoszewska B. [Ed]. Dziecko przewlekle chore - problemy medyczne, psychologiczne i pedagogiczne. Torun : Wyd. Edukacyjne AKAPIT.

Skorny Z. (1989). Rewalidacja dzieci chorych i niepetnosprawnych fizycznie a uczestnictwo $w$ dziataniu. Szkoła specjalna, 1 .

Tobiasz-Adamczyk B. (2002). Wybrane elementy socjologii zdrowia i choroby. Kraków: Wyd. Uniwersytetu Jagiellońskiego.

Tojza A. (2003). Opieka i wsparcie udzielane dziecku z choroba nowotworowa [In:] Marzec-Holka K. [Ed.]. Pomoc spoteczna, praca socjalna. Bydgoszcz: Wyd. UKW.

Wrześniewski K., Włodarczyk D. (2006). Rola wsparcia społecznego w leczeniu i rehabilitacji osób po zawale serca [In:] Sęk H., Cieślak R. [Ed.]: Wsparcie społeczne, stres i zdrowie. Warszawa: PWN.

Żółkowska T. (1994). Rodzina a funkcjonowanie w klasie szkolnej ucznia upośledzonego umysłowo w stopniu lekkim. Szczecin: Wyd. Uniwersytetu Szczecińskiego. 